\title{
Karstification of Ordovician carbonate reservoirs in Huanghua depression and its control factors
}

\author{
Jinning Zhang ${ }^{1,2,3} \odot$. Jiansheng Zhou ${ }^{1} \cdot$ Lixin Fu $^{1} \cdot$ Hongjun $\mathrm{Li}^{1} \cdot \mathrm{Da} \mathrm{Lou}^{1}$
}

Accepted: 25 February 2020 / Published online: 17 March 2020

(c) The Author(s) 2020

\begin{abstract}
With extensive ancient karsts and abundant oil and gas resources, the Ordovician carbonate reservoirs in the Huanghua depression have broad prospects of exploration and development. The types, characteristics, distribution and controlling factors of karsts were investigated by means of the analysis of cores, thin slices, logging, seismic, and geochemical data in this study. The study reveals that the Ordovician carbonate reservoirs in the Huanghua depression falls into three main categories, pore type, pore-vug-fracture type and fracture type, of which, pore-vug-fracture reservoirs account for $62 \%$. The epigenetic uniform karst mainly developed in the Late Ordovician to Early Carboniferous, while the differential karst developed in the Mesozoic. The uniform karstification mainly include chemical dissolution of the original carbonate rock, while the differential karstification not only include chemical dissolution but also hydraulic erosion and biochemical dissolution by organic acid. The burial karstification mainly involved the dissolution of the Ordovician reservoir by large amount of acidic fluids generated by the overlying Upper Paleozoic coal measure source rock while generating hydrocarbon. The dissolution caused by upwelling magmatic-tectonic hydrothermal fluids along faults also contributed to the formation of burial karst reservoirs. The sedimentation-diagenesis and paleogeomorphology-tectonic movement have certain control effects on the karstification of the Ordovician reservoirs in the Huanghua depression, determining the reservoir quality.
\end{abstract}

Keywords Ordovician · Karstification · Surface karst · Burial karst $\cdot$ Carbonate rock $\cdot$ Huanghua depression

\section{Introduction}

Studies on karst and reservoirs started in the 1960s abroad (Roehl 1967; Ford and Ewers 1978; Estebar and Klappa 1983; James and Choquette 1984). With the rise of the oil and gas industry, study on karst reservoir has also advanced and gradually become a systematic discipline, karstology. Chinese karstology study started back in the 1970s (Tang 1978). To the 1990s, with the rise of China's oil and gas industry, the study on karst and oil and gas reservoirs in

Jinning Zhang

zhjn0610@foxmail.com

1 Dagang Oilfield Company, PetroChina, Tianjin 300280, China

2 Shandong Provincial Key Laboratory of Depositional Mineralization and Sedimentary Mineral, Shandong University of Science and Technology, Qingdao 266000, China

3 Research Institute of Petroleum Exploration and Development, CNPC, Beijing 100083, China
China basically went shoulder and shoulder with those abroad. Some achievements on karstology study and oil discoveries were made in the Ordos Basin, Sichuan Basin and Tarim Basin (Su et al. 2015; Zhang et al. 2017; Fu et al. 2017; Xu et al. 2017; Li et al. 2017; Han et al. 2017).

The oil and gas exploration targeting Ordovician karst reservoir of Huanghua depression in the central of the Bohai Bay Basin started early in the 1970s but failed to make major discoveries due to the lack of basic geological understanding. Since the discovery of the high production Ordovician reservoirs inside Qianmiqiao Buried hill and Kongxi buried hill in the late 1990s, basic geological research on Ordovician has received due attention (Yu et al. 1999; Jiang 2000; Wang et al. 2000). Subsequently, industrial oil and gas flows were tapped in several Ordovician carbonate karst reservoirs in Gangbei buried hill, Wumaying-Wangguantun buried hill, Chenghai buried hill, Zhaodong buried hill and Nandagang buried hill (Fu et al. 2002, 2010, 2013; Zhang et al. 2019a). Therefore, to study karstification of the Ordovician carbonate rocks in the Huanghua depression, we examined the petrologic features and classified the karst reservoirs 
through core observation, thin section identification, well logging analysis and core CT scanning, sorted out controlling factors of karstification through analysis of carbon and oxygen isotope, strontium isotope and fluid inclusions and defined the lateral and vertical distribution of karstification using 3D seismic and 2D seismic data. The study will enrich and improve the basic geological information of the Ordovician reservoir in the buried hill, and provide the geological basis for the fine exploration of buried hill.

\section{Geological background}

The Huanghua depression is located in the central part of the Bohai Bay Basin in eastern China, and geologically between the Cangxian uplift and Chengning uplift, ending at Yanshan tectonic belt in the north., The depression, with an area of $1.8 \times 10^{4} \mathrm{~km}^{3}$, is a first-order negative structure of Bohai Bay Basin in eastern China (Fig. 1). The Huanghua depression has all strata from Proterozoic to Neogene,

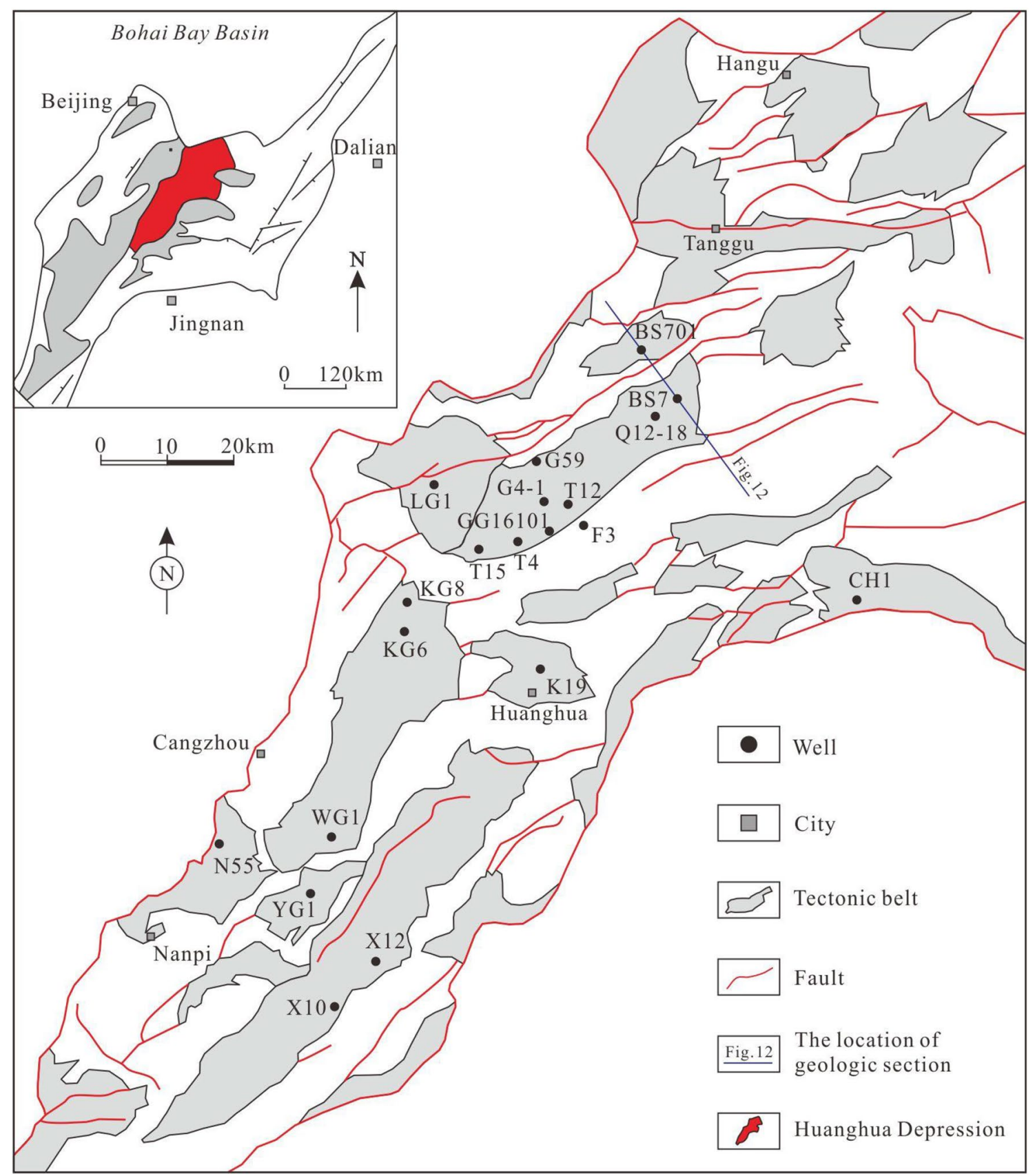

Fig. 1 Location map of the study area. The information of the map sources from the internal data of Dagang Oilfield Company 
which correspond to six major tectonic cycles, Jixian, Caledonian, Hercynian, Indosinian, Yanshanian and Himalayan (Meng et al. 2014). The Upper Proterozoic to Lower Paleozoic Cambrian and Ordovician in the Huanghua depression are marine deposits of epicontinental sea facies on stable craton dominated by marine carbonate strata, with minor coastal clastic strata between the Lower Cambrian and the Lower Proterozoic (Zhang et al. 1999; Zhao et al. 2017). Caledonian tectonic movement happened in North China during middle-late Ordovician; from Silurian to early Carboniferous, North china experienced regional uplift and a depositional hiatus of $120 \mathrm{Ma}$, consequently, Silurian and Devonian strata are absent (Zhai 2010). From Carboniferous of Late Paleozoic, the North China craton entered the evolution period of large scale depression of in-land basin, and coal measures strata of alternative marine-continental facies deposited during late Carboniferous, and continental clastic strata deposited during Permian along with large scale marine regression. During Mesozoic, Huanghua depression experienced the Indosinian and Yanshan movements, Jurassic to Cretaceous and locally residual Triassic deposited, which represent products during the breakup of Huabei craton and are dominated by clastic strata in intracontinental faulted depression (Zhou et al. 2012). The lower Jurassic strata are mainly thick pebbly sandstone interbeded with coal measures, and the upper strata are composed of volcanic rock interbedded with graywacke. The Cretaceous is composed of purple mudstone and volcanic rock with sandstone interbeds. Affected by rifting activities of NNE fault belts like Tanlu fault belt (Wang 2006; Zhu et al. 2010), during Cenozoic, Huanghua depression evolved from the initial rift in Eocene to extensional rift in Oligocene, going through several stages of rifting (Zhang et al. 2019b), Kongdian Formation, Shahejie Formation, Dongying Formation, Guantao Formation, Minhuazheng Formation and Pingyuan Formation deposited and from bottom to top, and subsidence center shifted several times, which can be divided into six stages of evolution (Fig. 2). Affected by multi-phases of tectonic movements, more than ten oil-bearing buried hill structures including, Qianmiqiao, Gangbei, Nandagang, Wangguantun and Wumaying are formed in Huanghua depression. With a large quantity of oil and gas resources, the Ordovician in the Huanghua depression is the major target of buried hill reservoir exploration and has broad prospects of exploration and development.

\section{Data and study methods}

The cores this study were all taken from Ordovician carbonate intervals in 50 exploration wells of the Huanghua depression. The wells are at Heilongcun uplift, Kongdian uplift, Qinan sub-depression, Gangxi uplift, Qibei sub-depression

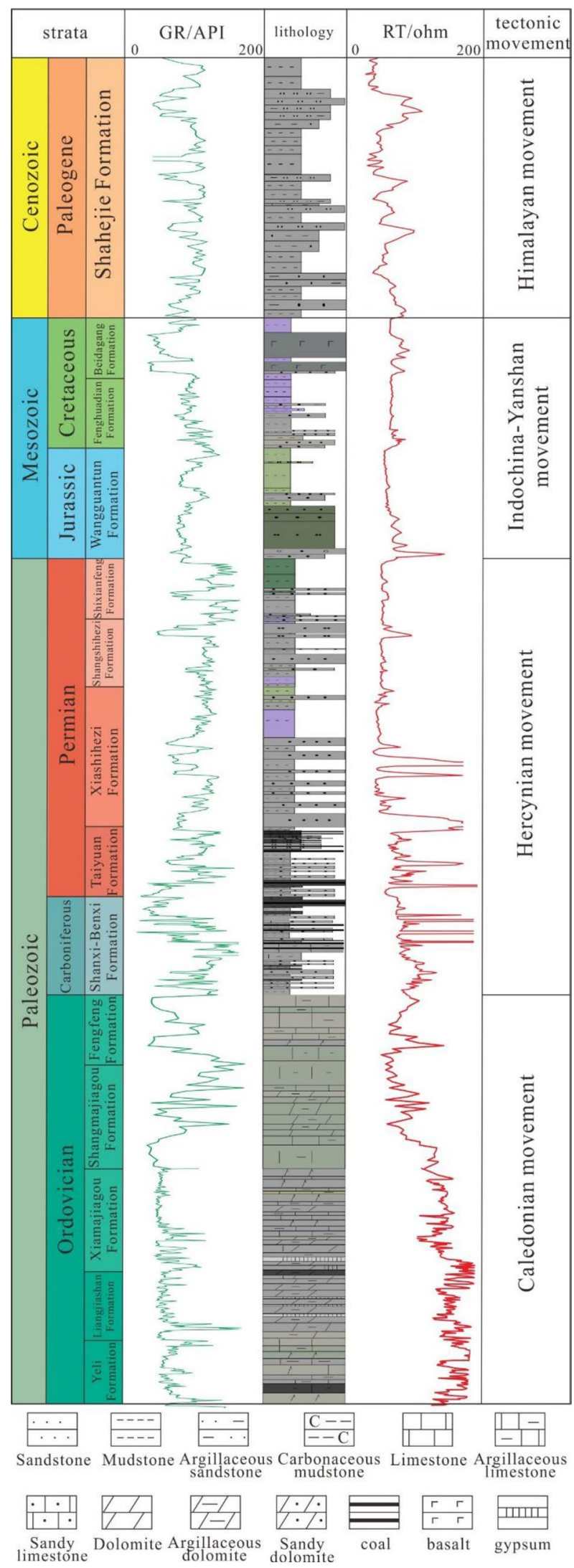

Fig. 2 The strata frame of the Huanghua depression. The information of the map sources from the internal data of Dagang Oilfield Company 
and Chengbei uplift and the core recovery rates of all the coring intervals are nearly $100 \%$. Over 100 samples in total were collected from cores of these 50 wells, and thin sections were observed with a Leica DMLP polarizing microscope.

Cores from Well GG16101 were scanned with a 16-bit $\mathrm{X}$-ray CT scanner with high resolution and micro focus in the State Key Laboratory of Coal Resources and Safe Mining of China University of Mining and Technology.

Fluid inclusions in eight of the over 100 core samples were tested in the Beijing Research Institute of Uranium Geology with a THMSG-600 hot and cold table system produced by British Linkam Company at the temperature range of $-196{ }^{\circ} \mathrm{C}$ to $600{ }^{\circ} \mathrm{C}$, homogenization temperature reproduction error of less than $2{ }^{\circ} \mathrm{C}$ and freezing point temperature reproduction error of less than $0.2^{\circ} \mathrm{C}$.

Fifty-five samples were ground and tested for carbon and oxygen isotopes at the Experimental Center of Earth Sciences and Technology Institute of Southwest Petroleum
University with MAT-252EM gas stable isotope ratio mass spectrometer manufactured by Finnigan, USA.

The 3D seismic data and logging data used this study are provided by Dagang Oilfield Company of PetroChina. The seismic data has a trace spacing of $25 \mathrm{~m} \times 25 \mathrm{~m}$ and an area of $7654 \mathrm{~m}^{2}$.

\section{Characteristics of Ordovician reservoir}

According to the core observation and thin slice identification of 50 wells such as Well GG16101, T12 and BS7, the pore space of Ordovician reservoir in Huanghua depression is mainly composed of primary pores, dissolved pores, vugs and fractures. In this paper, the reservoirs are classified into pore type, pore-vug-fracture type and fracture type (Fig. 3).

The first type, the pore type reservoir mainly contains dolomite and limestone primary pores, and most dolomite

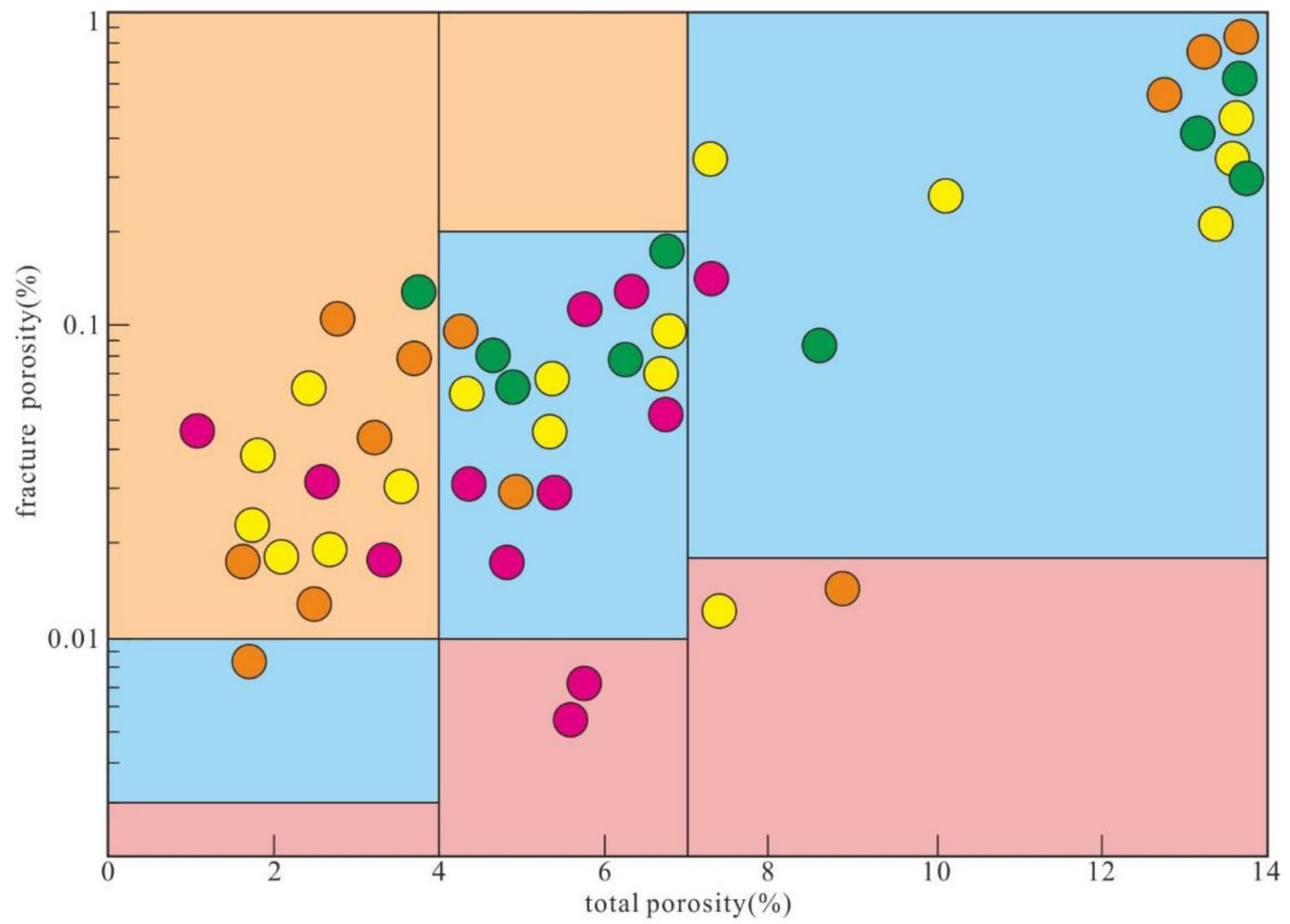

pore reservoirs

pore-vuggy-fractured reservoirs

fractured reservoirs
Fengfeng Formation

Shangmajiagou Formation

Xiamajiagou Formation

Liangjiashan Formation

Fig. 3 Classification of the Ordovician karst reservoirs in the Huanghua depression 
primary pores are filled by late cement. According to sample statistics, this kind of reservoir accounts for $8 \%$ of the total.

The second type, the pore-vug-fracture type reservoir, is controlled by karstification and tectonic fractures jointly. Karstification is the key factor affecting the quality of the reservoir. Most of the buried hill reservoirs in Huanghua depression are pore-vug-fracture ones, accounting for $62 \%$ of the total. Especially, the reservoirs in the area of Beidagang to Qianmiqiao have large numbers of fractures, dissolved pores and vugs in the cores (Fig. 4). The fractures and dissolved pores in the cores are not completely filled with cement, so the effective pores can serve as favorable reservoir space, and the reservoir is high in quality and the focus of oil and gas exploration in the Huanghua depression.

The third type, the fracture-type reservoir, which is characterized by low matrix porosity but higher permeability, has mainly fracture-vugs controlled by tectonic fractures as main storage space. This type of reservoir is widely distributed in Hunghua depression, accounting for $30 \%$ of the total samples. The carbonate reservoir within tectonic fracture or broken belt of fault is dissolved or cemented, and some unfilled fractures become favorable storage space of oil and gas (Fig. 5).

\section{Analysis of reservoir karstification}

There are three types of Ordovician carbonate reservoirs in the Huanghua depression, among which, the pore-vugfracture type shows features of intense karstification. The available data reveals the karstification includes two types, epigenetic karstification and burial karst. Due to the different mechanisms, they have differences in petrological characteristics.

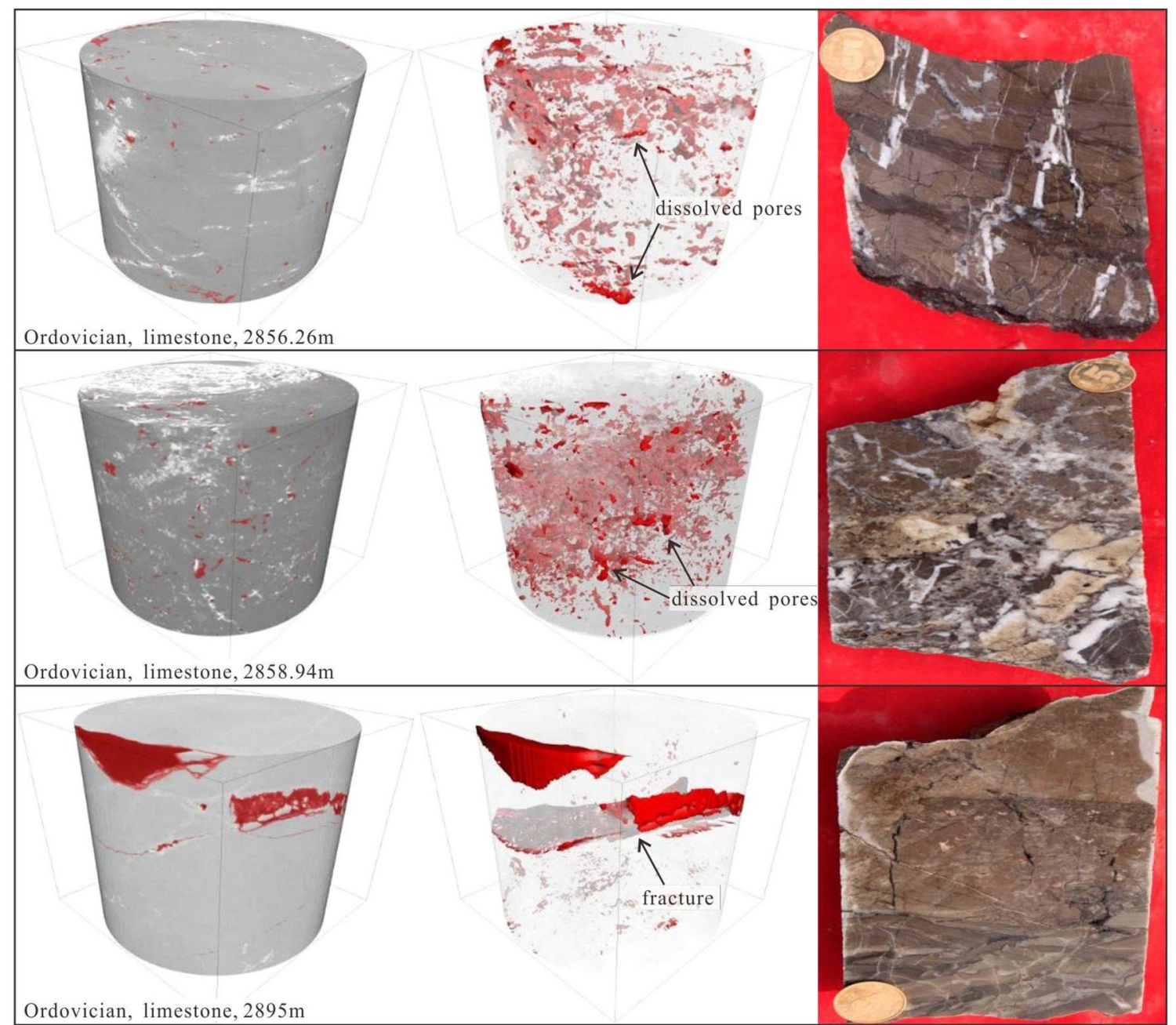

Fig. 4 CT scan images of cores from the Ordovician karst reservoir in Well GG16101. Fractures and secondary dissolution pores are abundant 

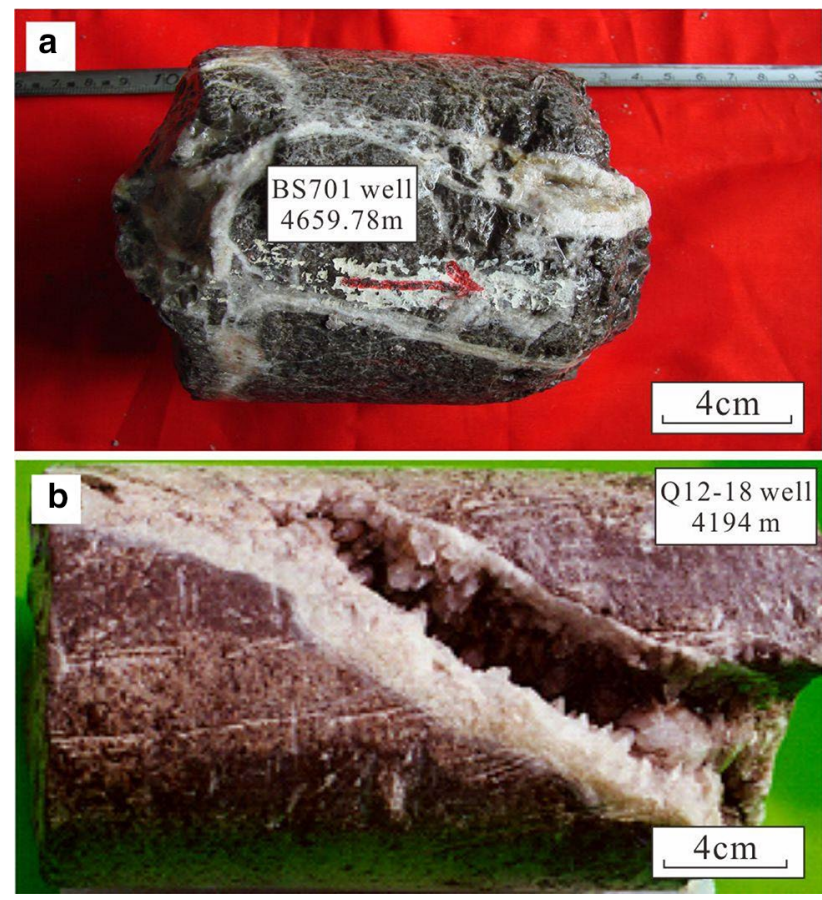

Fig. 5 Core characteristics of fractured reservoirs in the Huanghua depression. a Core from Well BS701, 4659.78 m, Fengfeng Formation, with high angle fractures filled by calcite; b Core from Well Q12-18, 4194 m, Fengfeng Formation of Ordovician, with large fractures partially filled by calcite

\section{Epigenetic karst reservoir}

\section{Geochemical characteristics}

The dolomite and calcite minerals fillings of the samples were tested for $\delta 13 \mathrm{C}$ and $\delta 18 \mathrm{O}$, and the results show that dolomite and calcite minerals produced by karstification have small ranges of $\delta 13 \mathrm{C}$ (PDB) and $\delta 18 \mathrm{O}$ (PDB) (Fig. 6), with $\delta 13 \mathrm{C}(\mathrm{PDB})$ values ranging from -5.52 to -1.33 , $-1.07 \%$ on average; and $\delta 18 \mathrm{O}(\mathrm{PDB})$ values ranging from -15.9 to $-6.03,-9.37 \%$ on average. The obvious negative value of $\delta 180$ indicates that the fillings of dissolved pore-vug-fracture was affected by meteoric freshwater, reflecting the epigenetic weathered crust environment of the karstification. A few samples have highly negative $\delta 180$ (PDB) values, which may be related to burial karstification.

$\mathrm{The} \mathrm{Sr} / \mathrm{Ba}$ ratio can reflect whether the carbonate rock is of seawater origin or freshwater origin (Loucks 1999; Mcmechan et al. 2002; Breesch et al. 2009). Generally, Sr/ $\mathrm{Ba}$ of freshwater facies sediment is less than 1 , while that of

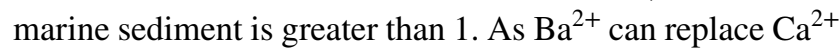
in sulfate and carbonate, the $\mathrm{Sr} / \mathrm{Ba}$ value of micritic dolomite containing anhydrite is more than 1 ; while the $\mathrm{Sr} / \mathrm{Ba}$ value of dolomite and limestone not containing anhydrite or gypsum pseudocrystals is less than 1 , suggesting they may be related to karstification of meteoric freshwater. Most samples from Ordovician reservoir in Huanghua depression have $\mathrm{Sr} / \mathrm{Ba}$

Fig. 6 Cross plot of carbon and oxygen isotopes of Ordovician carbonate rock samples from Huanghua depression

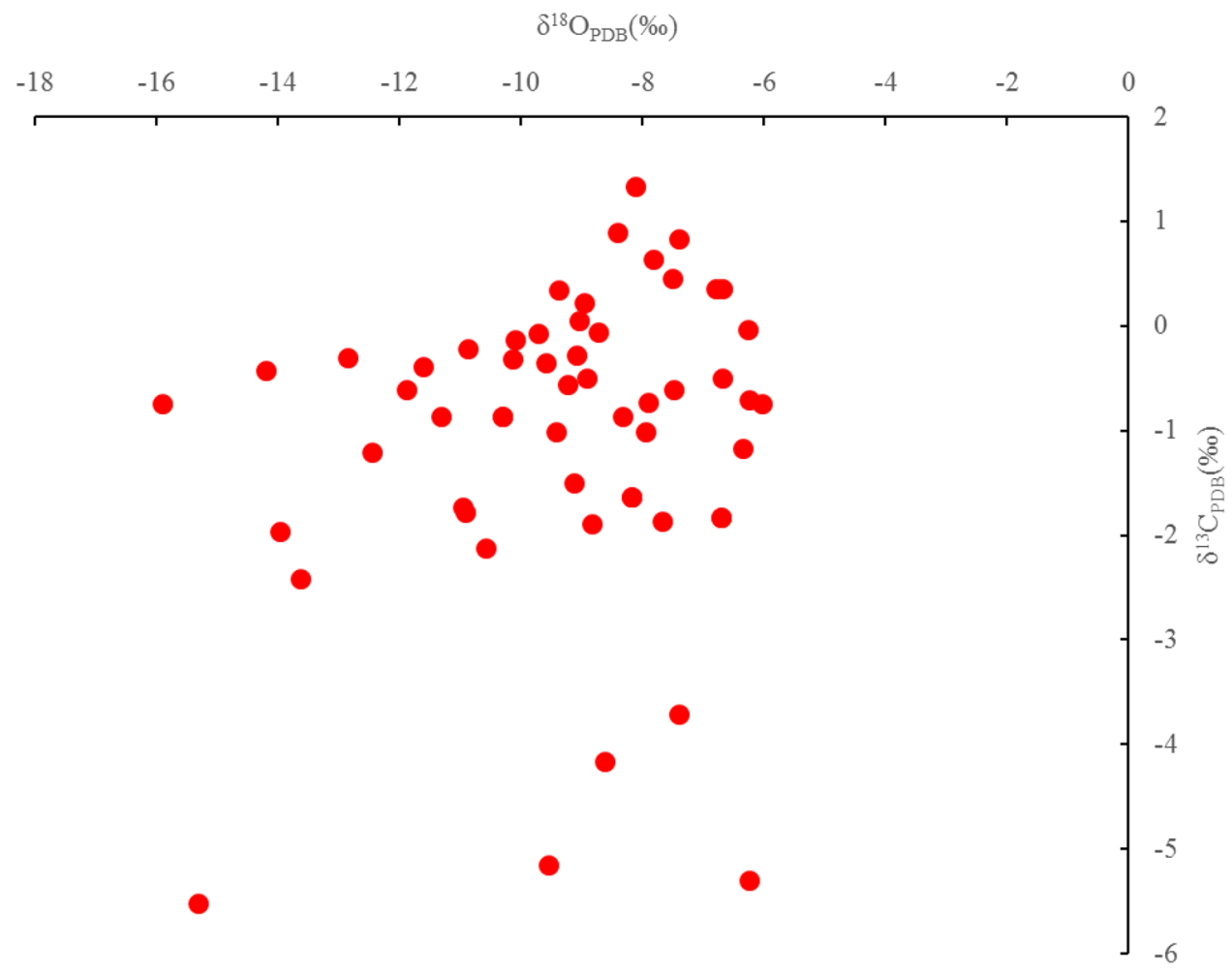


of less than 1, ranging between 0.109 and 0.952 (Table 1), indicating freshwater weathering and leaching background.

\section{Macroscopic and microscopic signs of epigenetic karstification reservoirs}

In epigenetic karstification, as the formation is exposed directly to the surface to suffer leaching by meteoric freshwater, while forming karst rock, the pores, vugs and fractures of karst would be filled with terrigenous materials (such as mud, silt sand and silt mud), neogenic minerals (such as bauxite, iron oxide, clay minerals, tuffaceous matter, and freshwater calcite), and insoluble residues in carbonate rocks (Fig. 7a, b). The dissolved pores and vugs filled with purple sparry calcite and bauxitite layer over weathered crust are commonly seen. For instance, in Well X12, X10 and $\mathrm{T} 4$, purple sparry calcite is seen along vugs, fractures and between grains (Fig. 7c). In Well T4, the bauxitite layer in weathered crust is nearly $3 \mathrm{~m}$ thick, and in Well K19, the bauxitite layer over weathered crust is even over $11 \mathrm{~m}$ thick. Gypsum/anhydrite pseudocrystals formed by surface dissolution-filling are observed in thin sections of some wells.

\section{Burial karstification reservoir}

In burial condition, as the diagenetic fluid contained acidic materials like $\mathrm{CO}_{2}, \mathrm{H}_{2} \mathrm{~S}$, organic acids and even hydrothermal fluids after the magma period, it would cause dissolution the surrounding rock, especially carbonate rock, giving rise to dissolved pores, vugs, and fractures and some new minerals. The homogenization temperature of fluid inclusion in a mineral is a good indicator of the ambient temperature and burial conditions at which the mineral is formed (Jiang et al. 2016). The mineral species associated with burial environment or hydrothermal activities can be seen on cores and thin sections, which include deformed dolomite, sphalerite, fluorite, pyrite, quartz, ankerite and ferroan calcite in some occurrences etc.

\section{Fluid inclusion characteristics}

The temperatures of the fluid inclusions in calcite filling in dissolved pores and vugs of the Ordovician reservoir were tested. It is found the fluid inclusions in the samples are mainly hydrocarbon-bearing brine inclusions formed after calcite filling in the limestone pores, most inclusions are in linear or in belt distribution along micro-cracks of calcite veins. The liquid hydrocarbon in the inclusions is light yellow or yellow, and sends out green and yellow-green fluorescence. The hydrocarbon gas in the inclusions is gray, with no fluorescence. Among these inclusions, oil inclusions account for $15 \%$, oil and gas inclusions account for $60 \%$, and gas inclusions account for $25 \%$. The temperature measurement results show that inclusions of the 106 samples have a homogenization temperature range from 96 to $168^{\circ} \mathrm{C}$, and an average of $135^{\circ} \mathrm{C}$ (Fig. 8), which is much higher than the normal formation temperature. The inclusions have a salinity range from 0.18 to 22.31 , and $7.65 \%$ on average, which is much higher than the normal seawater salinity. The test results show that the reservoir has experienced reformation by high-temperature brine fluid.

Some gas inclusions in the samples contain methane, methane content of some inclusions reaches $100 \%$. Some gas inclusions also contain acidic gas such as $\mathrm{CO}_{2}$ and $\mathrm{H}_{2} \mathrm{~S}$. Some liquid inclusions contain a small amount of $\mathrm{CO}_{2}$, $\mathrm{H}_{2} \mathrm{~S}$ and methane. Twenty-six samples contain methane, accounting for approximately $52 \%$ (Table 2). Nine samples contain $\mathrm{H}_{2} \mathrm{~S}$, accounting for approximately $18 \%$. The acidic fluid from the evolution of hydrocarbons was mixed into the burial karst fluid, causing organic acid dissolution to the Ordovician reservoir.

Table $1 \mathrm{Sr} / \mathrm{Ba}$ analysis data of Ordovician reservoirs in Huanghua depression

\begin{tabular}{lllllll}
\hline Well name & Well depth $(\mathrm{m})$ & Horizon & Lithological description & $\mathrm{Sr}(\%)$ & $\mathrm{Ba}(\%)$ & $\mathrm{Sr} / \mathrm{Ba}$ \\
\hline K19 & 2173.55 & $\mathrm{O}_{2} f$ & Granular micrite with several calcite veins & 0.02542 & 0.23258 & 0.109 \\
GG4-1 & 2185.73 & $\mathrm{O}_{2} f$ & Micrite, with dissolved fractures filled by calcite & 0.03575 & 0.18746 & 0.191 \\
K19 & 2172.4 & $\mathrm{O}_{2} f$ & Granular micrite with calcite veins & 0.02142 & 0.10315 & 0.208 \\
G2035 & 3074.39 & $\mathrm{O}_{1} y$ & Dolomitic micrite, with dissolution pores filled by calcite & 0.05147 & 0.13589 & 0.379 \\
BS701 & 4621.98 & $\mathrm{O}_{1} y$ & Micrite with network calcite veins & 0.03033 & 0.05846 & 0.519 \\
KG8 & 3014.1 & $\mathrm{O}_{2} f$ & Micrite, with dissolution fractures filled by calcite & 0.01888 & 0.03364 & 0.562 \\
LG1 & 3901.3 & $\mathrm{O}_{2} s$ & Micritic dolomite, with dissolution cave filled by calcite & 0.01556 & 0.02087 & 0.746 \\
BS701 & 4656.76 & $\mathrm{O}_{1} y$ & Dolomitic karst breccia & 0.01338 & 0.01774 & 0.754 \\
N55 & 1973.44 & $\mathrm{O}_{2} f$ & Micritic dolomite with calcite veins & 0.00612 & 0.00782 & 0.783 \\
G2035 & 3072.03 & $\mathrm{O}_{1} y$ & Micrite limestone with calcite veins & 0.03851 & 0.04338 & 0.888 \\
CH1 & 2350.75 & $\mathrm{O}_{2} s$ & Powdered crystal dolomite with calcite veins and ferriferous & 0.01292 & 0.01357 & 0.952 \\
& & & calcite veins & & \\
\hline
\end{tabular}



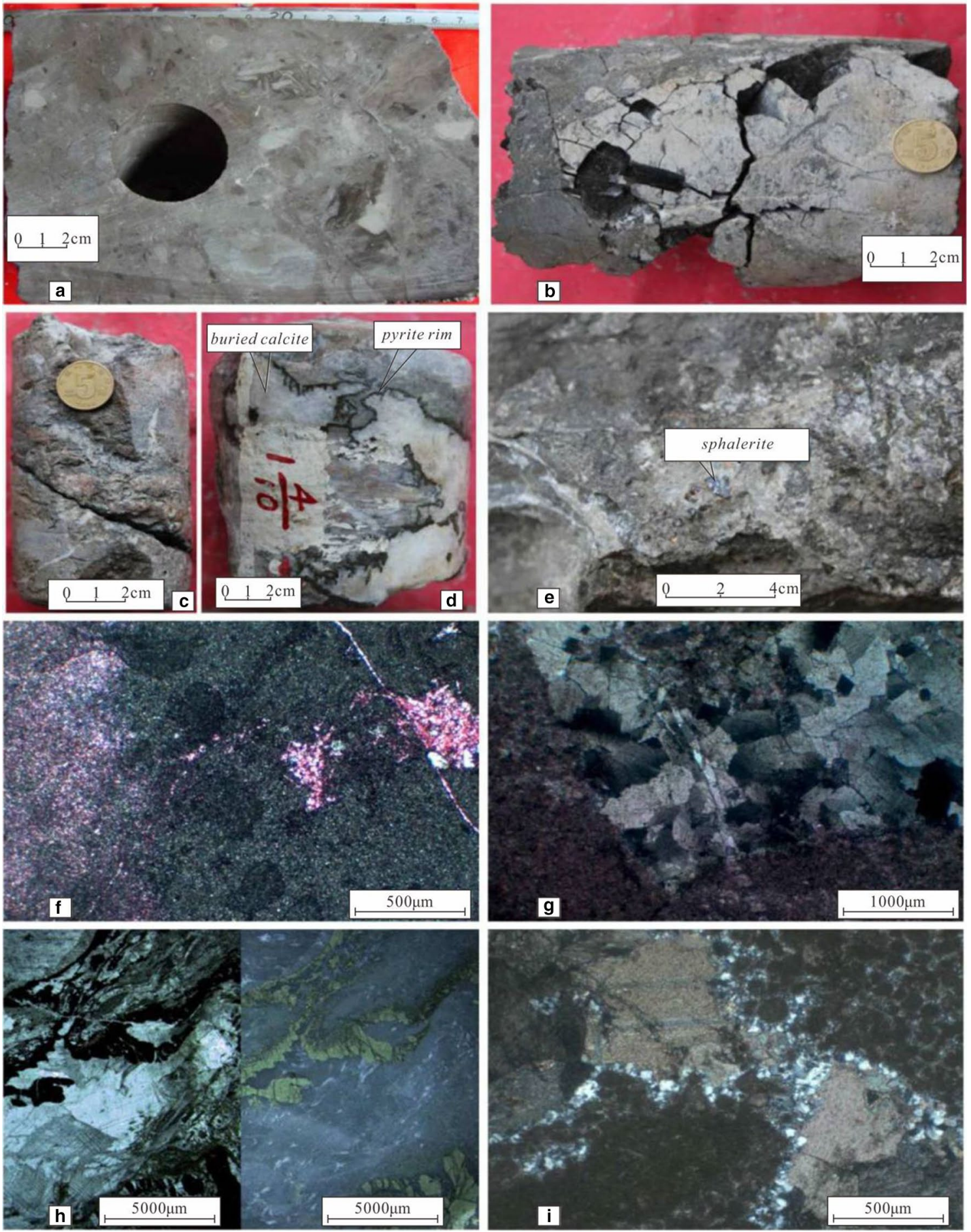

Fig. 7 Macroscopic and microscopic signs of reservoir karstification a Well Q12-18, 4192 m, Fengfeng Formation of Ordovician, dissolution caves filled with breccia; b Well LG1, 3690.21 m, Fengfeng Formation of Ordovician, caves filled with black limestone- argillaceous; c Well X12, 1464 m, Fengfeng Formation of Ordovician, greenish gray karst breccia, the purple breccia is coarse crystalline calcite; $\mathbf{d}$ Well T4, 2066.25 m, the Lower Majiagou Formation of the Ordovician, grey micrite with calcite vein, caves and pyrite ring along cave wall; e Well KG6, 2721 m, Upper Majiagou Formation of Ordovi-

cian, with sphalerite developed; f Well KG6, 2721.28 m, the Upper Majiagou Formation of Ordovician, fractures filled with purple-red sphalerite crystals (+), g Well CH1, 2227.39 m, Lower Majiagou Formation of Ordovician, fractures and dissolved pores filled with coarse deformed dolomite (+), h Well BS701, 4459.78 m, Fengfeng Formation of Ordovician, fluorite in micritic dolomite(+); i Well T4, 2067 m, Fengfeng Formation of Ordovician, dissolved pores filled with pyrite ring $(+)$ 
Fig. 8 Homogenization temperature of hydrocarbon bearing brine inclusions of Well WG1

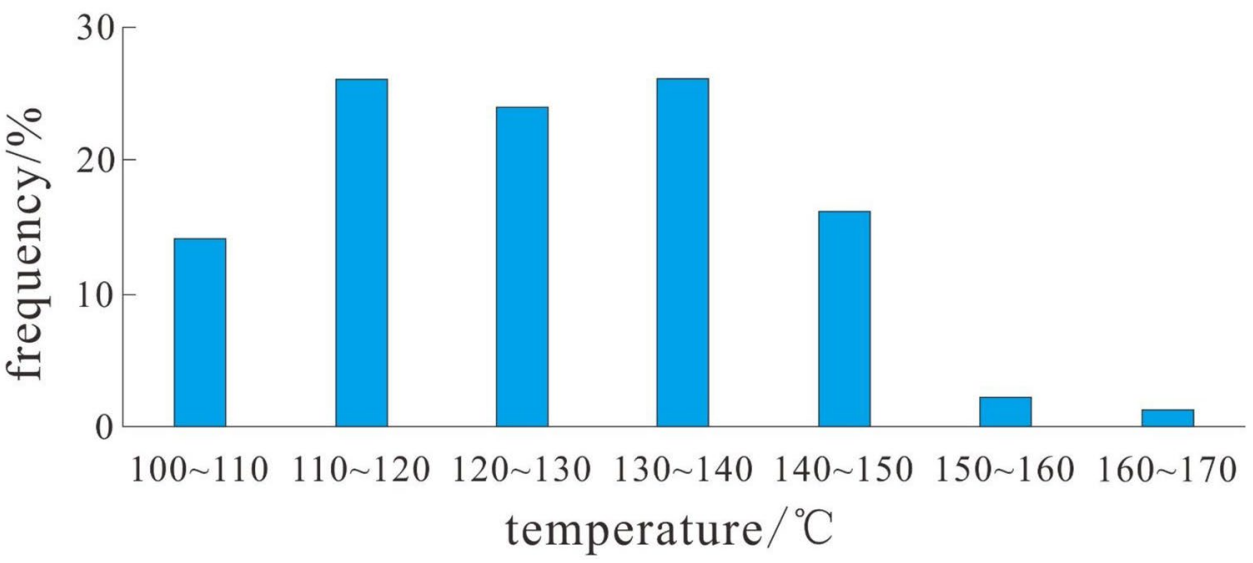

Table 2 Data of inclusion components

\begin{tabular}{|c|c|c|c|c|c|c|c|c|c|c|c|c|}
\hline \multirow[t]{2}{*}{ Well name } & \multirow[t]{2}{*}{ Well depth (m) } & \multicolumn{4}{|c|}{ Liquid inclusions (\%) } & \multicolumn{7}{|c|}{ Gaseous inclusions (\%) } \\
\hline & & $\mathrm{CO}_{2}$ & $\mathrm{H}_{2} \mathrm{~S}$ & $\mathrm{CH} 4$ & $\mathrm{H}_{2} \mathrm{O}$ & $\mathrm{CO}_{2}$ & $\mathrm{H}_{2} \mathrm{~S}$ & $\mathrm{CH}_{4}$ & $\mathrm{~N}_{2}$ & $\mathrm{H}_{2}$ & $\mathrm{C}_{2} \mathrm{H}_{4}$ & $\mathrm{C}_{6} \mathrm{H}_{6}$ \\
\hline BS701 & 4623.92 & 0.9 & & 0.2 & 98.9 & & 4.1 & 95.9 & & & & \\
\hline BS701 & 4648.78 & 1.2 & & 0.2 & 98.6 & & & 57.7 & & 42.3 & & \\
\hline BS701 & 4628.63 & & 0.3 & 0.4 & 99.2 & & 10.7 & 84 & & 5.3 & & \\
\hline K19 & 2378.07 & & 0.4 & & 99.6 & & & 46 & 54 & & & \\
\hline G2035 & 3070.39 & & & 0.9 & 99.1 & & & 80.6 & & 6 & 13.4 & \\
\hline LG1 & 3901.3 & & & 0.6 & 99.4 & & & 88.4 & & 4.8 & & 6.8 \\
\hline T9 & 2995 & & 0.3 & 0.3 & 99.4 & & & 69.7 & & 30.3 & & \\
\hline $\mathrm{T} 12$ & 1968.5 & & & & 100 & & & 72.9 & & 27.1 & & \\
\hline T15 & 2620.23 & & & 1.7 & 98.3 & & & 100 & & & & \\
\hline YG1 & 1577.26 & & & & 100 & 68.7 & 21.8 & & & 9.5 & & \\
\hline
\end{tabular}

\section{Macroscopic and microscopic signs of the burial karst reservoir}

Burial karstification mainly produces microscopic dissolved pores and specific diagenetic minerals. For example, dissolution pores filled with pyrite ring at pore wall and then coarse sparry calcite were seen at $30 \mathrm{~m}$ from the formation top in Well T4 (Fig. 7d). Sphalerite was found at the top of the upper Majiagou Formation in Well KG6 (Fig. 7e, f). Powdered micrite and dissolution pores and fractures filled with coarse crystalline anomalous dolomite were observed at lower Majiagou Formation in Well CH1 (Fig. 7g). Fluorite emitting blue light under cathodoluminescence was found in the micritic dolomite at $4659.78 \mathrm{~m}$ of Well BS701 (Fig. 7h). The appearance of this low-temperature hydrothermal mineral proves thermal fluid karstification and metasomatism happened during burial of the formation. Not only pyrite rings, but also giant crystal calcite and interlaced pyrite were also found in the dissolved pores and vugs at $30 \mathrm{~m}$ from the formation top in Well T4 (Fig. 7i).

\section{Development and control factors of karstification}

\section{Epigenetic karstification}

The regional tectonic movement caused the rise of fall of the sedimentary basin. The epigenetic karstification took place when the formation outcropped. Therefore, tectonic movement controls the development of epigenetic karstification. The Ordovician in the Huanghua depression experienced two stages of weathering and leaching (Zhang et al. 2019b). The first stage is the Late Ordovician to Early Carboniferous, during which the Huanghua depression experienced overall uplifting, and the whole Ordovician outcropped above the ground, so the karstification of this first stage is uniform karstification (Fu et al. 2016). The second stage is from Late Triassic to Late Jurassic, during which the northern part of the Ordovician in the Huanghua depression outcropped, while the southern part didn't crop out of the surface, so the karstification of this stage is differential karstification. 


\section{Development characteristics of uniform karstification}

The background of uniform karstification in the Huanghua depression was the vertical uplifting of vast area of carbonate platform with similar lithology and initial flat geomorphology but no faults and fractures (Fig. 9). In the process of dissolution of the dense carbonate rock of similar lithology by meteoric freshwater, there weren't enough fractures and geomorphic difference to guide meteoric freshwater to move and erode along specific vertical direction, resulting in similar karstification strength laterally and no obvious vertical karst geomorphology difference.

The development of uniform karstification needs three basic conditions: flat initial landform, no vertical faults and fractures, and dense and uniform lithology. For Huanghua depression, what we can tell from these three basic conditions is: (1) The initial topography in the interior of the Huanghua depression was flat; (2)the uplifting from late Ordovician to Early Carboniferous was overall uplifting, so there was no fault or fracture developed at early stage of the depression, and there were only folds and fractures developed at the edge of the depression; (3) Huanghua depression then was offshore carbonate platform where a large set of soluble but dense carbonate deposits with uniform lithology laterally developed.

Normally, karstification includes chemical dissolution and hydraulic erosion, but from Late Ordovician to Early
Carboniferous, the Ordovician carbonate in Huanghua depression only had chemical dissolution but no hydraulic erosion. The atmospheric precipitation with high $\mathrm{CO}_{2}$ content should have been very conducive to the dissolution of carbonate rock, but due to the flat original geomorphology and the lack of geological structures such as faults and fractures, when the atmospheric precipitation with high $\mathrm{CO}_{2}$ content fell on the ground, it flew on the ground surface and quickly flew away, and couldn't stay long to react with surface carbonate or get down deep, so the karstification wasn't high in intensity and failed to form karst landform differences. Since the Huangqi depression was flat during this period and there was not high enough slope, therefore, the hydraulic erosion then was weak, especially in the Late Ordovician. Only after the early Carboniferous when obvious topography or landform difference occurred, was the contribution of hydraulic erosion increased somewhat.

In the Huanghua depression, the uniform karstification produced small scale of dissolved pores, dissolved fractures and dissolved vugs, and karst caves in gypsum-salt layers across the area. The reservoir after this reformation turns better in storage capacity in general. Uniform karstification mainly took place on the surface, but the atmospheric freshwater rich in $\mathrm{CO}_{2}$ could also flow along the microscopic cracks generated by physical weathering and seep down vertically, and stay longer in the fractures, thus enhancing karstification intensity and producing
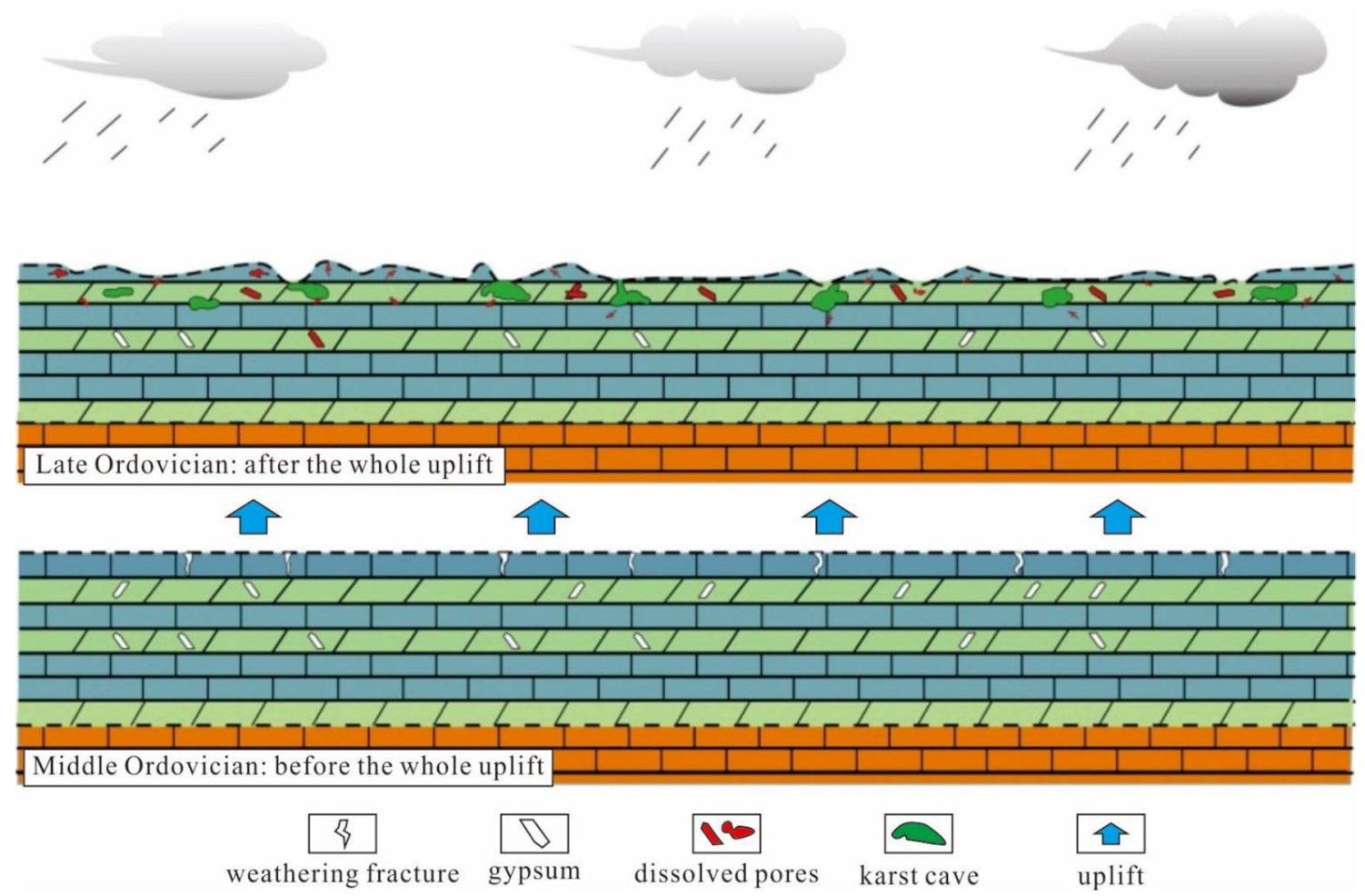

Fig. 9 Model of the uniform karstification of the Ordovician buried hill 
dissolved pores, dissolved vugs and fractures. The topography/landform difference would get bigger with time, the soluble evaporative salt minerals such as anhydrite would be dissolved in large scale, even forming karst caves. The topographic features in early uniform karstification were similar to those of the karst highland, while the later karst has both vadose dissolution and phreatic lateral dissolution, so it has features of both karst highlands and karst slope.

\section{Mechanism and occurrence of differential karstification}

Differential karstification happened in the Huanghua depression in the Mesozoic with intense dissolution, producing a large number of karst caves. The differential karstification came about, as differential uplifting of the basement and tectonic movements gave rise to faults, fractures and folds, and long-term uniform dissolution in the late stage of uniform karstification resulted in big difference in landform and widely distributed gullies in the outcrop area (Fig. 10). Based on the difference in topographic and tectonic setting, the differential karstification in Huaghua depression is
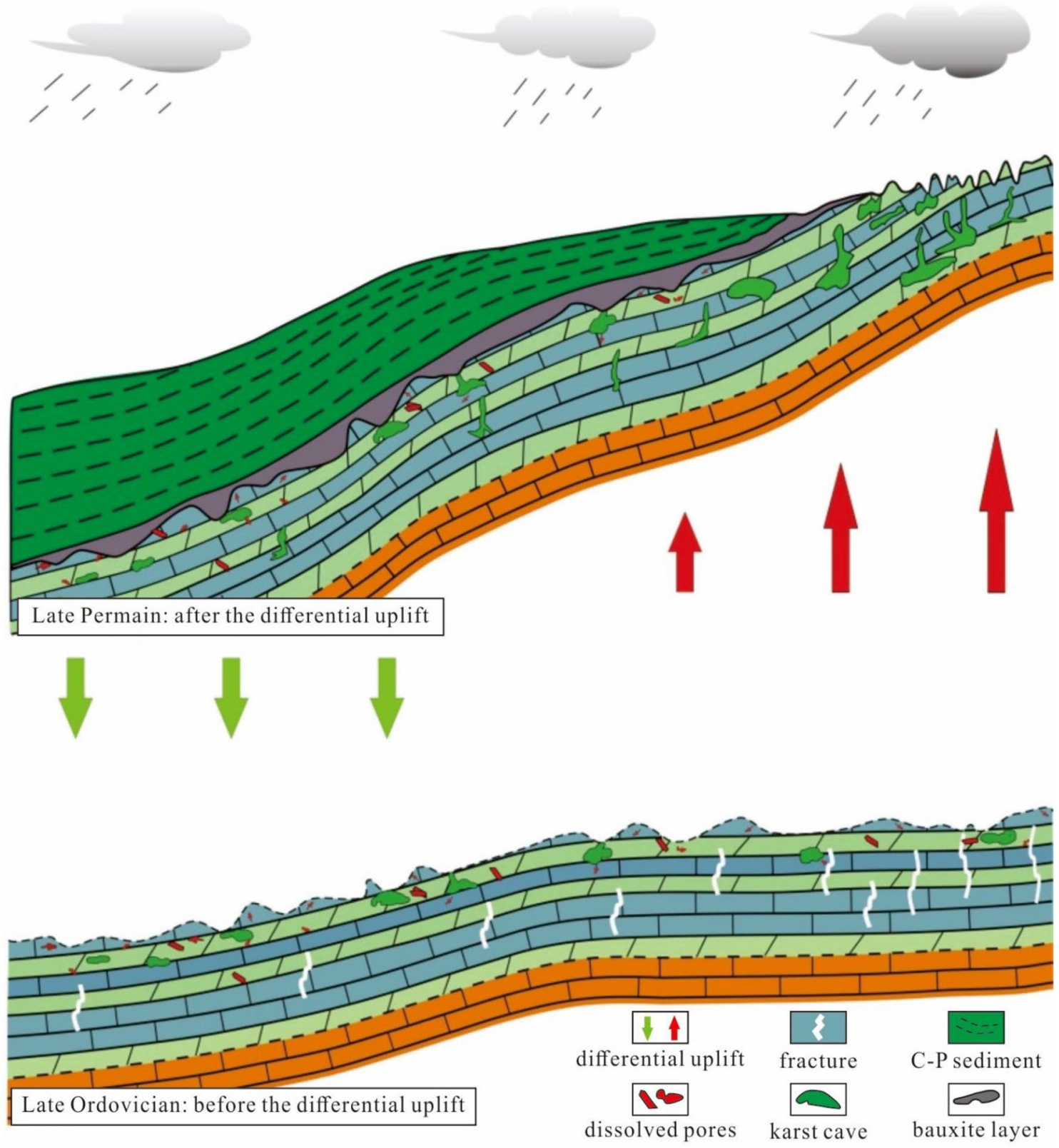

Fig. 10 Model of differential karstification of the Ordovician buried hill 
further divided into topographic differential karstification and tectonic differential karstification.

Under constraints of seismic data, the karst paleo-geomorphology was restored according to the contact relationship between the Ordovician and its overlying strata, the results show that differential karstification in the Huanghua depression mainly occurred in the northern part (Fig. 11).
The topographical differential karstification is essentially the aggravation of topographic difference caused by differences in dissolution duration and intensity resulted from original topographic difference, and the karst topographic difference would accordingly enlarge during exposure period. Different from uniform karstification, topographic differential karstification includes both chemical dissolution and hydraulic

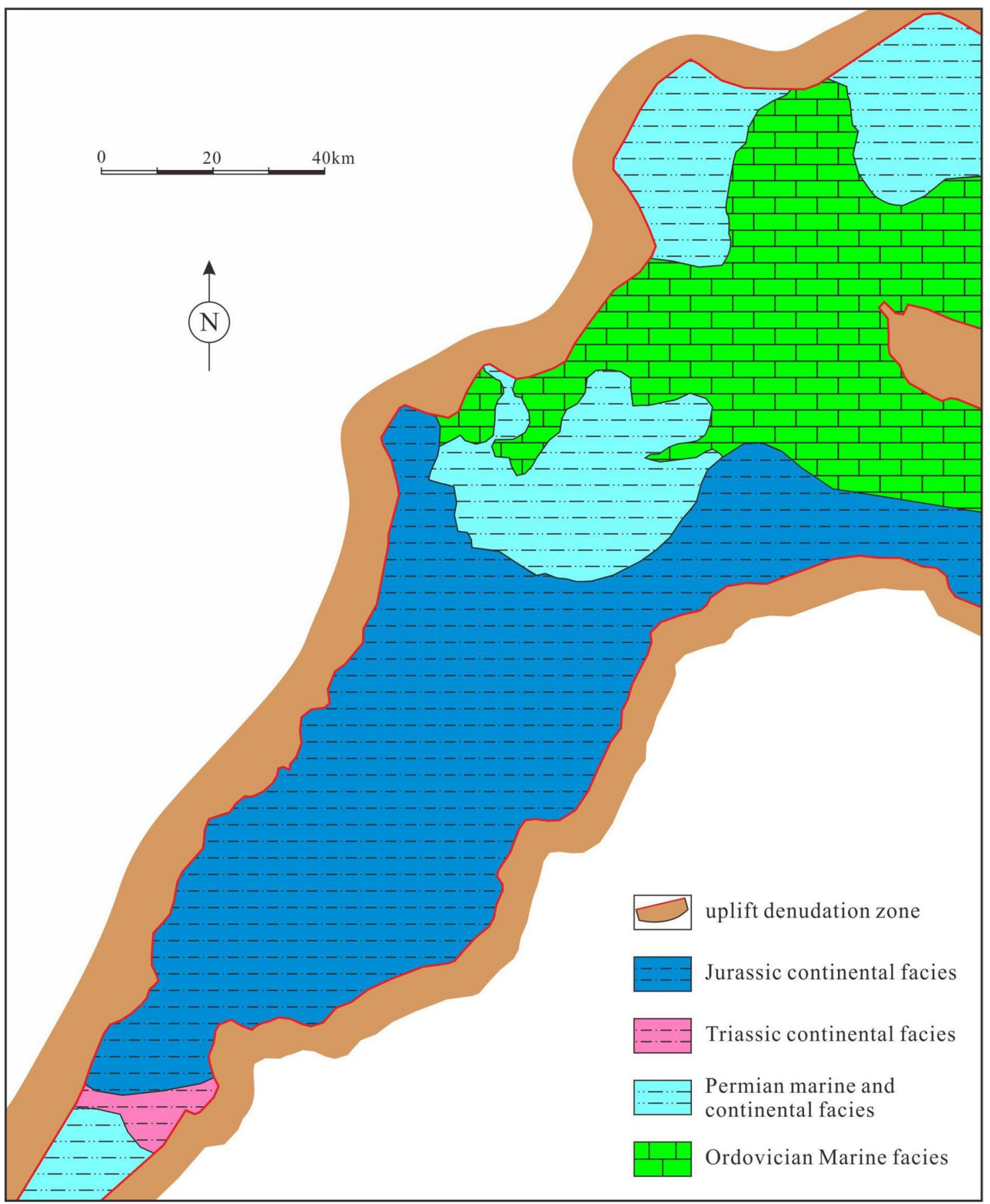

Fig. 11 Distribution of Ordovician epigenetic karstification in Mesozoic, the Huanghua depression 
erosion. As the topographic difference increases, the potential energy of the surface meteoric water, and therefore its erosion force when converted into kinetic energy will increase, accelerating karstification.

The tectonic differential karstification refers to vertical and lateral dissolution of meteoric freshwater to the primary carbonate rock along the faults and fractures etc. when meteoric water seeping along the faults and fractures, which could enhance the topographic difference, karst pore-vugfracture difference and even form karst caves. Huanghua depression has several discordogenic faults and a large number of structural fractures associated with the faults. Instead of running off and evaporating quickly as on the flat surface, the atmospheric precipitation rich in $\mathrm{CO}_{2}$ would enters the faults and fractures and be entrapped there longer, giving it sufficient time to react with the primary carbonate rock, to dissolve the primary rock and improve physical properties of the reservoir.

In general, the topographical differential karstification and tectonic differential karstification in the Huanghua depression are significantly different from the uniform karstification in the period, mode and intensity of karstification: (1) The karstification period is different, the uniform karstification happened mainly from the Late Ordovician to Early Carboniferous, while differential karstification took place in the Mesozoic; (2) uniform karstification merely include chemical dissolution of carbonate rock, while differential karstifciation not only include chemical dissolution, but also hydraulic erosion and biochemical dissolution of organic acids, so it is a combined effect of multiple kinds of dissolutions; (3) as the differential karstification is a combined effect of multiple dissolution processes, therefore it is higher in intensity, giving rise to more dissolved pores, vugs and caves, and better reservoirs.

\section{Burial karstification}

The burial karstification in the Huanghua depression occurred in the zone affected by the acidic fluid formed during the hydrocarbon generation of the Upper Paleozoic coal-measure source rock, and the magmatic-structural hydrothermal dissolution also contributed to the burial karst reservoir.

\section{Dissolution of organic acid generated during the maturation of upper Paleozoic coal-measure source rock}

The coal-measure source rock of Upper Paleozoic in the Huanghua depression is characterized by hydrocarbon generation in multiple stages (Zhang et al. 2008, 2019c). During hydrocarbon generation, the source rock would produce a large amount of acidic fluids such as $\mathrm{CO}_{2}$, to dissolve the adjacent Ordovician carbonate reservoir. Due to the high intensity of Mesozoic-Cenozoic tectonic movement in the Huanghua depression, a large number of tectonic fractures developed in the Ordovician, which on the one hand provided infiltration paths for the meteoric water rich in $\mathrm{CO}_{2}$, and on the other hand also acted as paths for organic acid entering the reservoir during the burial stage together with faults. The mixing of the two types of fluids provided conditions for burial karstification (Fig. 12), thereby improving reservoir quality.

\section{Dissolution of magma-structural hydrothermal fluid}

After Indosinian movement, the Huanghua depression experienced multiple stages of volcanic hydrothermal activities, among which the magma activity of Cenozoic was most

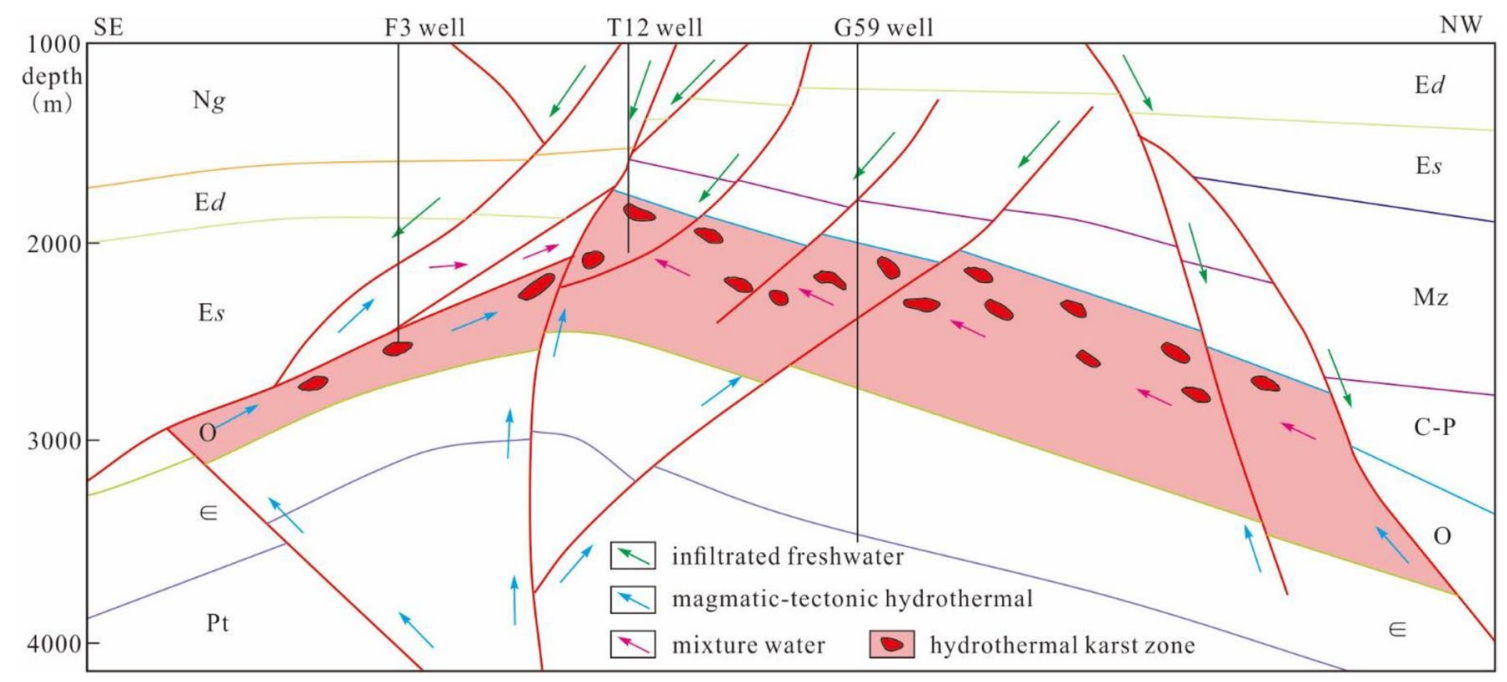

Fig. 12 Schematic diagram of magma-tectonic hydrothermal fluid karstification 
extensive (Yang et al. 2014; Zhang et al. 2014). The direct impacts of magmatic activity on the Ordovician carbonate rock in this area include dissolution and filling. In addition to silicates, metal minerals and radioactive elements, magma also contains some volatile components such as $\mathrm{H}_{2} \mathrm{O}, \mathrm{CO}_{2}$, $\mathrm{H}_{2} \mathrm{~S}, \mathrm{~F}, \mathrm{Cl}$ and so on. Water is the main component in the gas phase and liquid phase of the magma. When the hydrothermal fluid rich in $\mathrm{CO}_{2}$ and $\mathrm{H}_{2} \mathrm{~S}$ mixed with the heated atmospheric freshwater, and entered carbonate formation along faults and fractures, it would erode the carbonate rock. At this time, the dissolution basically happened along faults and fractures, and the reticular fractures are especially favorable for magma-structural hydrothermal karstification.

\section{Dominant factors controlling the development of karst reservoirs}

\section{Control of sedimentation and diagenesis on the development of karst reservoirs}

Sedimentation controls the distribution of soluble minerals such as anhydrite-rock salt. The Ordovician in the Huanghua depression generally consists of limestone, dolomite and gypsum dolomite-anhydrite. Due to the low energy constraint-evaporation environment during the Ordovician period, the sediment developed was characterized by fine structure carbonate with evaporite interbeds. The lower parts of lower Majiagou Formation, Upper Majiagou Formation and Fengfeng Formation of the Middle Ordovician contain anhydrite or anhydrite dolomite of different amount. These anhydrite dolomite and anhydrite would be dissolved easily when contact with meteoric freshwater, first forming dissolution pores and fractures, then caves and cave breccia when collapsed (Fig. 13). The dissolution pore and vug layers in Huanghua depression show some regularity in distribution
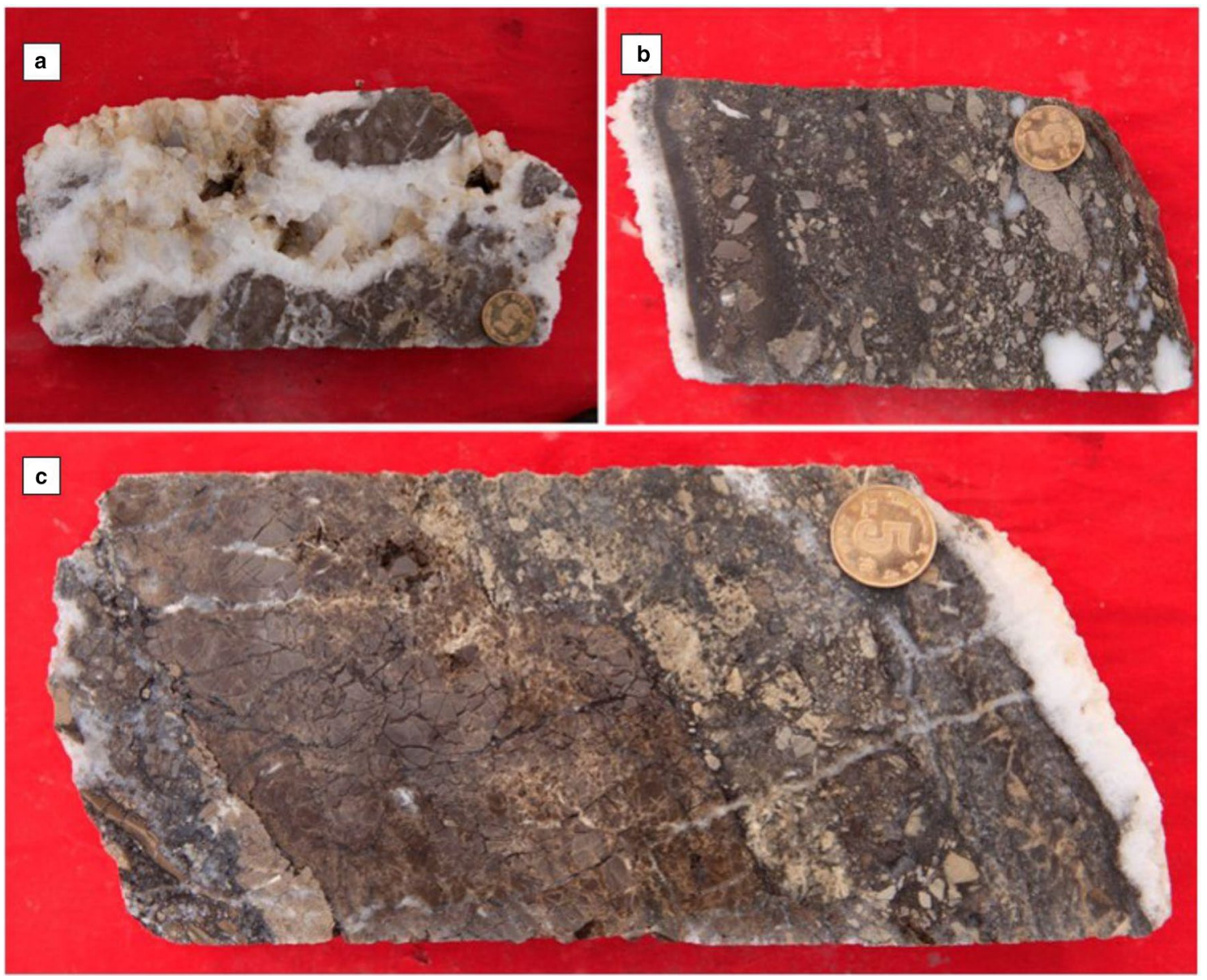

Fig. 13 Ordovician cave breccia in Well GG16101. $2857.28 \mathrm{~m}$, calcite filling dissolved caves with oil trace; b $2861.83 \mathrm{~m}$, breccia mixtite, dissolved cave filled with breccia; c $2861.63 \mathrm{~m}$, pebbly calcarenite, with normally graded bedding, dissolved pores, and caves 
and are mostly within about $100 \mathrm{~m}$ from weathering crust top.

The Upper Paleozoic coal measure source rock in the Huanghua depression overlies on the Ordovician, and the large amount of acidic fluid produced during hydrocarbon generation of the source rock would dissolve the underlying Ordovician reservoir. Therefore, the distribution scope of the coal measure strata controls the range of organic acid dissolution of Ordovician. The Upper Paleozoic coal measure strata are mainly distributed in the middle and south areas of the Huanghua depression, and are eroded out in the northern part due to uplifting during Mesozoic.

\section{Control of paleogeomorphology and tectonic movement on the development of karst reservoirs}

The control of tectonic movement on karstification in Huanghua depression is reflected in 3 aspects: (1) The tectonic movement controlled karst paleo-geomorphology and karstification of the outcropping zone of soluble rock, and affected the path of karstification water. (2) The tectonic movement controlled the formation and development of faults and fractures, and the intersected and intercrossed fracture system improved the permeability of the rock, altered the circulation system of karst water, and increased the dissolution area of the soluble rock. (3) The magmatic-structural hydrothermal fluid upwelling created a hydrothermal karst zone in the Ordovician reservoir adjacent to the large basement fault and volcanic channels, which together with other types of karstification enhanced reservoir property.

\section{Conclusions}

(1) The Ordovician carbonate reservoirs of the Huanghua depression have primary pores, dissolution pores and vugs, and fractures as main storage space, and can be divided into three main categories, pore type,, porevug-fracture type and fracture type. The pore-vug-fracture reservoirs accounting for $62 \%$ are the key targets of oil and gas exploration in Huanghua depression.

(2) The epigenetic uniform karstification of the Ordovician reservoir mainly took place in the Late Ordovician to Early Carboniferous, while the epigenetic differential karstification reservoir happened in the Mesozoic. The uniform karstification involves chemical dissolution of the carbonate primary rock, while the differential karstification not only includes chemical dissolution but also hydraulic erosion and biochemical organic acid dissolution. With several types of karstification working together, the karstification intensity of Ordovician reservoirs is high, and thus a large number of pores, fractures and caves were produced, forming dominant reservoirs.

(3) The burial karstification in the Huanghua depression mainly involves the dissolution of acidic fluid generated during the hydrocarbon generation of the Upper Paleozoic coal measure source rock to the underlying Ordovician reservoir, and the upgoing magmatic-structural hydrothermal fluid along fault also made a contribution to burial karst reservoir.

(4) Sedimentation-diagenesis and palaeogeomorphology tectonic movement have certain effects on the karstification of the Ordovician reservoir in the Huanghua depression, determining the reservoir quality.

Funding Funding was provided by the open fund of Shandong Provincial Key Laboratory of Depositional Mineralization \& Sedimentary Mineral (Grant No. DMSM2018047), the major science and technology projects of PetroChina Co Ltd (Grant No. 2018E-11-02).

Open Access This article is licensed under a Creative Commons Attribution 4.0 International License, which permits use, sharing, adaptation, distribution and reproduction in any medium or format, as long as you give appropriate credit to the original author(s) and the source, provide a link to the Creative Commons licence, and indicate if changes were made. The images or other third party material in this article are included in the article's Creative Commons licence, unless indicated otherwise in a credit line to the material. If material is not included in the article's Creative Commons licence and your intended use is not permitted by statutory regulation or exceeds the permitted use, you will need to obtain permission directly from the copyright holder. To view a copy of this licence, visit http://creativecommons.org/licenses/by/4.0/.

\section{References}

Breesch L, Stemmerik L, Wheeler W, Nordeide HC (2009) Fluid flow reconstruction in a complex paleocave system reservoir in wordiekammen, central spitsbergen. J Geochem Explor 101:10

Estebar M, Klappa C F (1983) Subaerial exposure environment. In: Sckolle PA, Bebout DG, Moore CH (eds). Carbonate depositional environments, vol 33. AAPG Mem, pp 1-95

Ford DC, Ewers RO (1978) The development of limestone cave systems in the dimensions of length depth. Can J Earth Sci 15:1978-1998

Fu LX, Chen SY, Wang DL, Liu SZ, Wang X (2002) Natural gas pool in Ordovician reservoir in Wumaying buried-hill and its formation history. Pet Explor Dev 29:25-27

Fu LX, Lou D, Feng JY, Si GS, Yan HZ (2010) Geologic features and hydrocarbon exploration potential of middle and low-buried Hill in Qikou Sag. Nat Gas Geosci 21:559-565 (in Chinese with English Abstract)

Fu LX, Wu XS, Zhao M, Guo SW, Wang H, Yang ZY, Feng JY (2013) Structural geology and gas accumulation in Ordovician reservoir in Chenghai buried-hill in Qikou sag. J Northeast Pet Univ 37:6372 (in Chinese with English Abstract)

Fu LX, Lou D, Li HJ, Qi JF, Feng JY, Guo JY, Wu XS, Zhao YG (2016) Control effect of Indosinian-Yanshan movement on the formation 
of buried hill in Dagang exploration area. Acta Pet Sinica 37:1930 (in Chinese with English Abstract)

Fu H, Han JH, Meng WB, Feng MS, Hao L, Gao YF, Guan YS (2017) Forming mechanism of the Ordovician karst carbonate reservoirs on the northern slope of Central Tarim Basin. Nat Gas Ind 37:2536 (in Chinese with English Abstract)

Han CC, Lin CY, Wei T, Dong CM, Ren LH, Zhang XG, Li D, Xu Z (2017) Paleogeomorphology restoration and the controlling effects of paleogeomorphology on karst reservoirs: a case study of an ordovician-aged section in Tahe oilfield, Tarim Basin, China. Carbonates Evaporites 34:1-14

James NP, Choquette PW (1984) Limestone-the Meteoric diagenetic environment. Geosci Can 11:161-194

Jiang P (2000) A pool formation analysis for Qianminqiao buried hill structure. Pet Explor Dev 27:14-16 (in Chinese with English Abstract)

Jiang Y, Tao Y, Gu Y, Wang J, Qiang Z, Jiang N, Lin G, Jiang C (2016) Hydrothermal dolomitization in dengying formation, gaoshitimoxi area, sichuan basin, SW china. Pet Explor Dev 43:54-64

Li YQ, Hou JG, Sun JF, Kang ZJ, Liu YM, Song SH, Han D (2017) Paleokarst reservoir features and their influence on production in the Tahe Oilfield, Tarim basin, China. Carbonates Evaporites 33:1-12

Loucks RG (1999) Paleocave carbonate reservoirs: origins, burialdepth modification, spatial complexity, and reservoir implications. AAPG Bull 83:1795-1834

Mcmechan GA, Loucks RG, Mescher P, Zeng X (2002) Characterization of a coalesced, collapsed paleocave reservoir analog using gpr and well-core data. Geophysics 67:1148-1158

Meng QR, Wei HH, Wu GL, Duan L (2014) Early Mesozoic tectonic settings of the northern North China craton. Tectonophysics 611(1):155-166

Roehl P (1967) Stony Mountain (Ordovician) and Interlake (Silurian) facies analogs of recent low-energy marine and subaerial carbonates, Bahamas. AAPG Bull 51:1979-2032

Su ZT, Liu N, Yang WJ, Hu SC, Wu CY, Pei WC, Ren JF (2015) Types and models of supergene karst of Ordovician and reservoir characteristics in Ordos basin. Carsologica Sinica 34:109-114 (in Chinese with English Abstract)

Tan ZD (1978) The control significance of structure to Karst. J Changchun Inst Geol 6:43-47 (in Chinese)

Wang Y (2006) The onset of the Tan-Lu fault movement in eastern China: constraints from zircon (SHRIMP) and ${ }^{40} \mathrm{Ar} /{ }^{39} \mathrm{Ar}$ dating. Terra Nova 18:423-431

Wang TG, Wang FY, Lu H, Tang YJ, Yang CY, Liao QJ, Zhou JS, Sun XM (2000) Oil source and accumulation period of Ordovician reservoir in Kongxi buried hill zone, Huanghua Depression. Mar Pet Geol 5:47-54 (in Chinese)

Xu XH, Chen QL, Chu CL, Li GR, Liu CG, Shi Z (2017) Tectonic evolution and paleokarstification of carbonate rocks in the Paleozoic Tarim Basin. Carbonates Evaporites 32:487-496

Yang QY, Santosh M, Shen JF, Li SR (2014) Juvenile vs. recycled crust in NE China: Zircon U-Pb geochronology, Hf isotope and an integrated model for Mesozoic gold mineralization in the Jiaodong Peninsula. Gondwana Res 25:1445-1468

Yu XM, Su JQ, Wang ZS (1999) Basic geological characteristics of Qianmiqiao buried hill reservoir. Pet Explor Dev 26:7-9 (in Chinese with English Abstract)

Zhai MG (2010) Tectonic evolution and metallogenesis of North China Craton. Miner Depos 29:24-36 (in Chinese with English Abstract)

Zhang H, Chen GL, He ZL (1999) Control of palaeoclimatic change on Late Palaeozoic coal Accumuation of the North China Plate. Acta Geol Sin 73:131-139 (in Chinese with English Abstract)

Zhang TW, Zhang MJ, Bai BJ, Wang XB, Li LW (2008) Origin and accumulation of carbon dioxide in the Huanghua depression, Bohai Bay Basin, China. AAPG Bull 92:341-358

Zhang ZM, Dong X, Santosh M, Zhao GC (2014) Metamorphism and tectonic evolution of the Lhasa terrane, Central Tibet. Gondwana Res 25:170-189

Zhang YF, Tan F, Xu HZ, Zhong ZQ, Liu Y, Luo XS, Wang ZY, Xu $F$ (2017) Karst monadnock fine characterization and reservoir control analysis: a case from Ordovician weathering paleokarst reservoirs in Lungu area, Tarim Basin, NW China. Pet Explor Dev 44:716-726

Zhang JN, Zhou JS, Fu LX, Li HJ, Lou D, Feng JY, Wu XS, Yang ZY, Li HS, Zhao YG (2019a) Geological characteristics and accumulation process of natural gas reservoirs in Gangbei buried hill, Huanghua depression. J China Univ Min Technol 48:980-991 (in Chinese with English Abstract)

Zhang JN, Fu LX, Zhou JS, Lou D, Li HJ, Zhao YG, Feng JY, Wang X (2019b) The macroscopic distribution characteristics and evolution process of buried hill in Huanghua depression, Bohai bay basin. J Geol 93:585-596 (in Chinese with English Abstract)

Zhang JN, Zhou LH, Zhou JS, Xiao DQ, Han GM, Zhao M, Fu LX, Li HJ, Lou D, Wang H (2019c) Control of mesozoic tectonic movement on hydrocarbon generation and evolution of upper paleozoic coal measure source rocks in Huanghua depression. Nat Gas Ind 39:1-10 (in Chinese with English Abstract)

Zhao Y, Zhai MG, ChenZhang HSH (2017) Paleozoic-early Jurassic tectonic evolution of North China Craton and its adjacent orogenic belts. Geol China 44:44-60 (in Chinese with English Abstract)

Zhou LH, Fu LX, Lou D, Lu Y, Feng JY, Zhou SH, Santosh M, Li SZ (2012) Structural anatomy and dynamics of evolution of the Qikou Sag, Bohai Bay Basin: implications for the destruction of North China craton. J Asian Earth Sci 47:94-106

Zhu G, Niu ML, Xie CL, Wang YS (2010) Sinistral to normal faulting along the Tan-Lu Fault Zone: evidence for geodynamic switching of the East China continental margin. J Geol 118:277-293

Publisher's Note Springer Nature remains neutral with regard to jurisdictional claims in published maps and institutional affiliations. 